\title{
Development of Podcasts as Teaching Materials for Students of Higher Education in the Pandemic Covid-19
}

\author{
Faiz 'Urfan*, Ayu Sekar Ningrum, Kronika Br. Ginting \\ Study Program of Geography Education \\ Universitas Samudra \\ Langsa City, Indonesia \\ *faiz.urfan@unsam.ac.id, ayusekarningrum@gmail.com, kronikaginting74@gmail.com
}

\begin{abstract}
The Covid-19 pandemic has driven many universities in Indonesia to conduct online learning. However, the implementation of online learning has encountered many obstacles, one of which is the uneven network quality and the low purchasing power of students for internet packages. This has an impact on decreasing the effectiveness of online student learning to take lectures online. The purpose of this research is to develop podcasts as teaching materials for university students in online learning. The media used for the publication of teaching materials is Google Podcasts on the link https://bit.ly/3fGC3IU. The podcast's theme is writing thesis and scientific articles. The method used in this research is Research and Development (R\&D). Respondents in this study were 124 students from five universities in Indonesia. The results of this study indicate that podcasts can reduce obstacles in online learning. The main advantage felt by respondents was the ease of access to teaching materials even though the quality of the internet network was inadequate. Besides, students do not spend a lot of money to buy internet packages because the podcast file size is relatively small. Based on this research, the recommendation put forward is that the development of online teaching materials should pay attention to the economic conditions of students so that learning objectives can be achieved properly.
\end{abstract}

Keywords—podcasts, teaching materials, online learning, pandemic covid-19

\section{INTRODUCTION}

Learning process in the classroom must be interactive, inspirational, fun, challenging, motivating, and provide sufficient space for initiatives. However, with the Covid-19 outbreak that has hit the world, it has provided new challenges for the world of education, one of which is the learning process in universities in Indonesia. The Indonesian government has banned universities from holding conventional lectures that instructed them to conduct lectures through online learning. Therefore, learning in college will not be as effective as usual. In fact, the task of the teacher or lecture is to make learning easy for students. They must provide opportunities for them to understand and apply learning material in life. To achieve this goal, lecture must consider student characteristics based on their learning styles [1]. The high demands for teaching and the demands for the use of new technology in higher education are increasing, so lecturers often look for new and innovative ways to convey teaching material in interesting ways [2].

The online learning system requires students to study from home (distance learning). Almost all of the universities in Indonesia implementing an online lecture system. Lecturers are required to compile online teaching materials that can be understood by students in the form of documents, slide shows, and videos. The most popular teaching materials for online learning are videos distributed via YouTube or ZOOM. However, the use of YouTube and ZOOM can increase internet data usage and must also be supported by a good quality of network. Based on the authors' experience, many students in university live in peripheral areas with limited internet network access.

Based on these problems, it is necessary to take effective action. Lecturers must make online teaching materials that are easily accessible to students with poor signal quality. One of the online teaching materials that are considered capable of answering this problem is a podcast [3]-[5]. Podcast is a teaching material in the form of audio that made from sound recordings and can be accessed via internet. Besides, podcasts can be addressed as audio files available online for listening through a number of technological devices, including smartphones, MP3 players, personal computers, tablets, and more [2], [6]. The presence of podcasting technology encourages new opportunities in educational settings. The potential of podcasts to support students in learning has been recognized for a long time. Podcasts can be a source of information, motivation and inspiration for students as well as lectures. Podcasts have the same power as radio, namely a more personal and informal touch through the human voice [1]. While still a relatively new technology, podcasts, as well as the portable devices they use, are changing how people interact with media. Today, urban peoples, campuses and fitness 
centers are populated by people using smartphones as a means of continuing to listen to the podcast or music of their choice [7], [8]. Listening is the first step in the learning process. Even the formation of language must begin with the listening process. The more the listening process is carried out, the better the language mastery will be [9]. Podcast duration and repetitive listening have a positive effect on the ability to understand humans through voice information [10], [11]. The created podcasts can be uploaded to the internet via many online platforms, such as Google Podcasts. Google Podcasts is a podcast application that anyone can access for free. Today's use of podcasting represents an integrated, extensible and creative technology. The increased use of technology marks a gradual shift from technology-based teaching strategies. New uses include the use of podcasting as a marketing tool to increase student motivation [12], [13]. The in-app download feature allows podcasts to be played back even if there is no internet connection. In addition, the small file size makes the podcast easily accessible to students with poor internet signal quality. Based on these arguments, it is urgent to develop podcasts as teaching materials in universities. Podcasts development as a teaching material can anticipate the limitations of internet facilities for students as well as fulfill their needs for learning.

\section{RESEARCH METHODS}

This research was conducted in Indonesia by taking a sample of students from five universities. The number of respondents involved was 124 people. The research method used was Research and Development (R\&D). The objective of $\mathrm{R} \& \mathrm{D}$ is to develop podcasts as online teaching materials. The theme of the podcast developed is the writing and publication of scientific articles. The R\&D stages carried out are as follows: (1) a preliminary study in the form of research and information collecting; (2) developing a product that summarizes six activities namely (a) planning; (b) developing preliminary forms of product; (c) preliminary field testing; (d) main product revision; (e) main field testing; (f) operational product revision; (3) product validation which summarizes three activities namely (a) operational field testing; (b) final product revision; (c) dissemination, and implementation. Every step of R\&D Data was analyzed descriptively based on feedback from respondents supported by data from Google Analytics.

\section{RESULTS AND DISCUSSIONS}

The output of this research is a podcast with the theme of writing and publication of scientific articles. The podcast is uploaded to Google Podcasts with the channel name 'Skripsi Beres!' On the link https://bit.ly/3fGC3IU. These podcasts consist of ten episodes of about 10 minutes each. As written in the research method section, the process of making podcasts has gone through the following R\&D steps. The list of episodes is as follows.

Episode 1 - Cari Judul Kok Susah Episode 2 - Kenapa Harus Baca Dulu
Episode 3 - Antara Pisau dan Gergaji

Episode 4 - Memisahkan Emas dari Tanah

Episode 5 - Penelitian Lintas Generasi

Episode 6 - Mengapa Harus Menulis Artikel Ilmiah

Episode 7 - IMRAD

Episode 8 - State of the Art

Episode 9 - Berburu Jurnal untuk Publikasi

Episode 10 - Finale - It's Time to Leap!

\section{A. Preliminary Study}

Preliminary studies are conducted to prepare for the podcast development process. Preliminary studies are carried out by gathering material and analyzing needs. The needs analysis was carried out through a questionnaire distributed online to Universitas Samudra's students. Based on the results of the needs analysis, Samudra University students still have obstacles in online learning. In addition, their level of understanding about the writing and publication of scientific articles is still low.

\section{B. Developing a Product}

The product developed is a podcast with the theme of writing and publishing scientific articles for high education students. To produce a quality podcast, product development is carried out in six stages as follows.

1) Planning: The language used in the podcast is Indonesian because the target of product development is students with the first language of Indonesian. Podcast consists of ten episodes that are arranged in a systematic manner. Podcast complexity is organized from simple to complex levels.

2) Developing preliminary forms of product: The first thing that is done in preparing this podcast is determining the title for each episode. The use of Indonesian in this podcast is informal Indonesian so it is easier for students to accept. Podcasting using a laptop, a headphone and a microphone. This activity is carried out by recording and then editing the recording. Sound recording and editing process using Audacity 2.4.2 for Windows 10 .

3) Preliminary field testing: After the Podcast was completed, a trial was conducted based on the research sample to assess how much benefit it would have on improving student learning. Podcasts that are created are not uploaded to the internet, but are distributed via a Google Drive link to respondents. Then the Podcast testing was revised, to fix the shortcomings of the product so that this trial method would be better in the future. Based on the feedback of respondents (124 people) at the preliminary field-testing stage, podcasts have weaknesses in the aspects of voice clarity and intonation suitability. The data feedback can be seen in figure 1 .

Based on the data in figure 1 , there are five aspects of podcast quality assessment. The aspect of assessment with the highest value is depth of material and duration accuracy. Meanwhile, the assessment aspects with the lowest scores were 
voice clarity and intonation suitability. Then the aspect with value at the medium stage is the attractiveness of language.

4) Main product revision: Podcast revisions are carried out according to respondents' feedback at the preliminary field-testing stage, so that the aspects that need to be improved are voice clarity and intonation suitability. Then the podcast quality in the other three aspects needs to be maintained.

5) Main Field Testing: The first podcast revision has been completed, namely by increasing voice clarity and intonation suitability. Podcasts are retried on the same respondents so that the podcasts can be evaluated objectively and consistently. Figure 2 shows the respondents' feedback on the podcast on the first improved version.

Based on the feedback from respondents shown in figure 2, it can be concluded that there is an increase in the quality of the first improved version of the podcast compared to the preliminary form version of the podcast. There is an increase in the aspects of voice clarity and intonation suitability. This is indicated by the majority of respondents who gave very good responses for both aspects. Then, the other three aspects did not decrease in value. This condition shows that the depth of material, the attractiveness of language and duration accuracy does not experience a decrease in quality.

6) Operational product revision: Even though respondents have given a fairly good rating to the first improved version of the podcast, the podcast still needs quality improvement. Therefore, podcasts are improved for the second time in order to produce podcasts that are worthy of being used as teaching materials in higher education.

\section{Product Validation}

The final stage of developing podcasts as online teaching materials is product validation. This stage is the second podcast improvement to optimize all quality aspects in a podcast. Respondents were given different questionnaires to find out their assessment of the final product developed. In addition, researchers also used data from Google Analytics which is available on the Google Podcasts website. Google Analytics for podcasts provides accurate and real time data so that researchers can evaluate podcasts that have been created as teaching materials in higher education.
1) Operational field testing: The operational stage testing is carried out through Google Podcasts, so that respondents can assess the accessibility of content through channels that can be accessed publicly. Even so, respondents are still given the same questionnaire at this stage. The results of filling out the questionnaire by respondents can be seen in Figure 3.

Based on the data in Figure 3, the podcast quality in all aspects shows good results. This is shown in the graph which is high in the answer choices 'excellence' and 'very good'. Meanwhile, the assessments 'weak' and 'insufficient' are already at a very low number. This data indicates that two improvements to the podcast have had a significant impact on improving quality.

2) Final product revision: In the final product revision, there was no improvement in the quality of the podcast because the respondents' ratings were very good. This indicates that the podcast developed is in accordance with the respondent's standards and is ready for general distribution.

3) Dissemination and implementation: Podcast content is exported in mp3 format and then uploaded to Google Podcasts in channel 'Skripsi Beres!'. The link to access this podcast is https://bit.ly/3fGC3IU. After being uploaded to Google Podcasts, researchers can measure the popularity of podcasts among internet users. This popularity can indicate internet users' interest in podcast content that has been developed. In figure 4 and figure 5, Google Analytics results are displayed.

Based on Google Analytics data in figure 4 and figure 5, the number of minutes played is at a fairly high level with an average of 50,085 minutes for three months. In addition, the number of episodes listened to by internet users is quite high. Episode 1, episode 2, and episode 10 are the episodes most listened to by internet users. In figure 6 , you can see the respondent's assessment of the podcasts that have been uploaded to Google Podcasts. The graphic in figure 6 shows that this podcast has had a positive impact on internet users who are looking for teaching materials in writing and publishing scientific papers. 


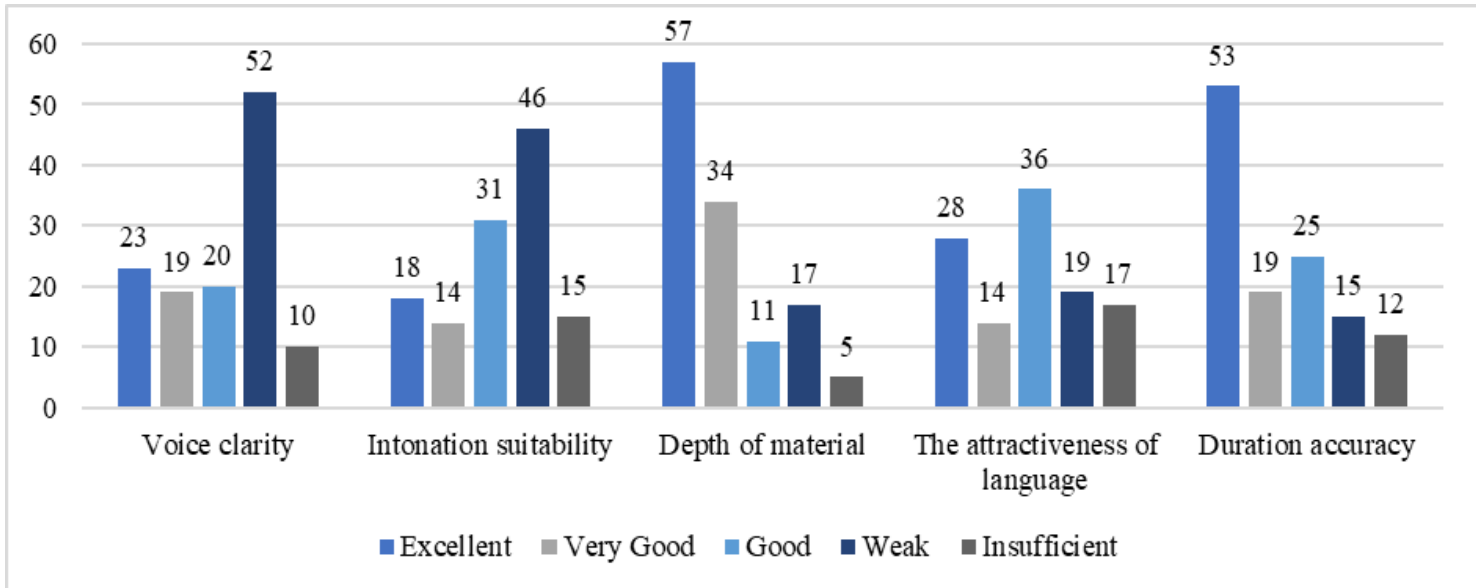

Source: Research Data, 2020

Fig. 1. Respondent feedback at the preliminary field-testing stage.

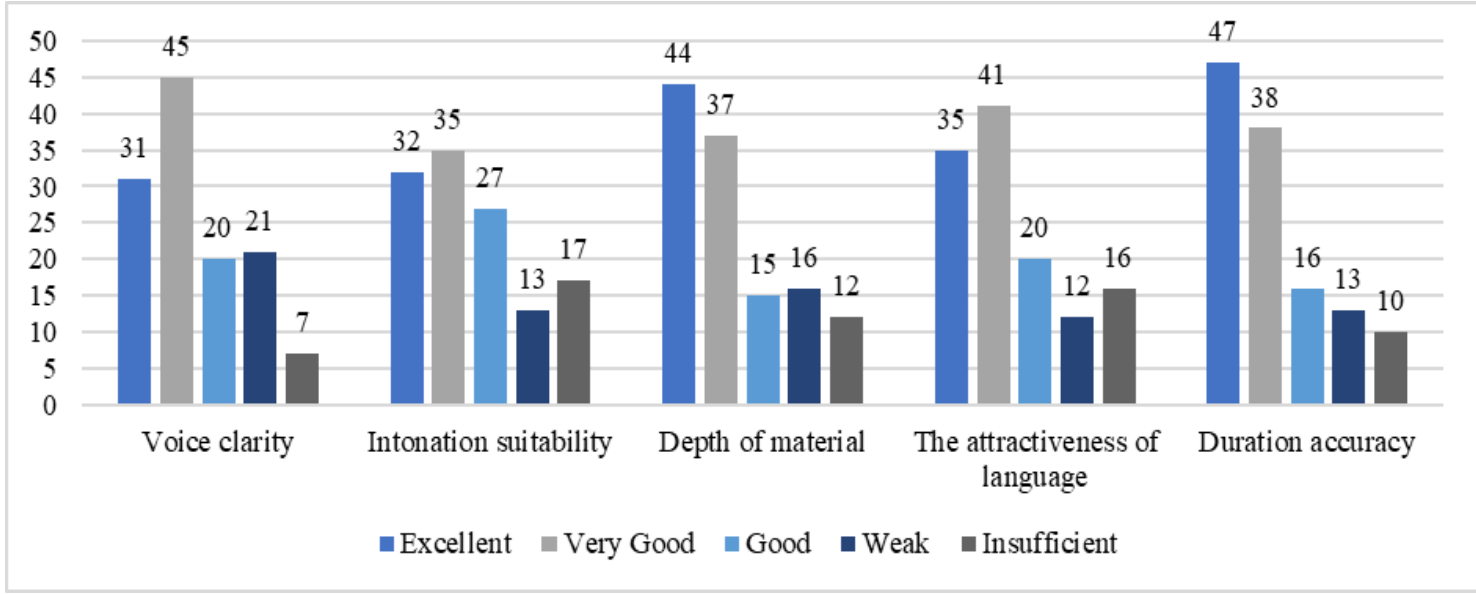

Source: Research Data, 2020

Fig. 2. Respondent feedback at the main field-testing stage.

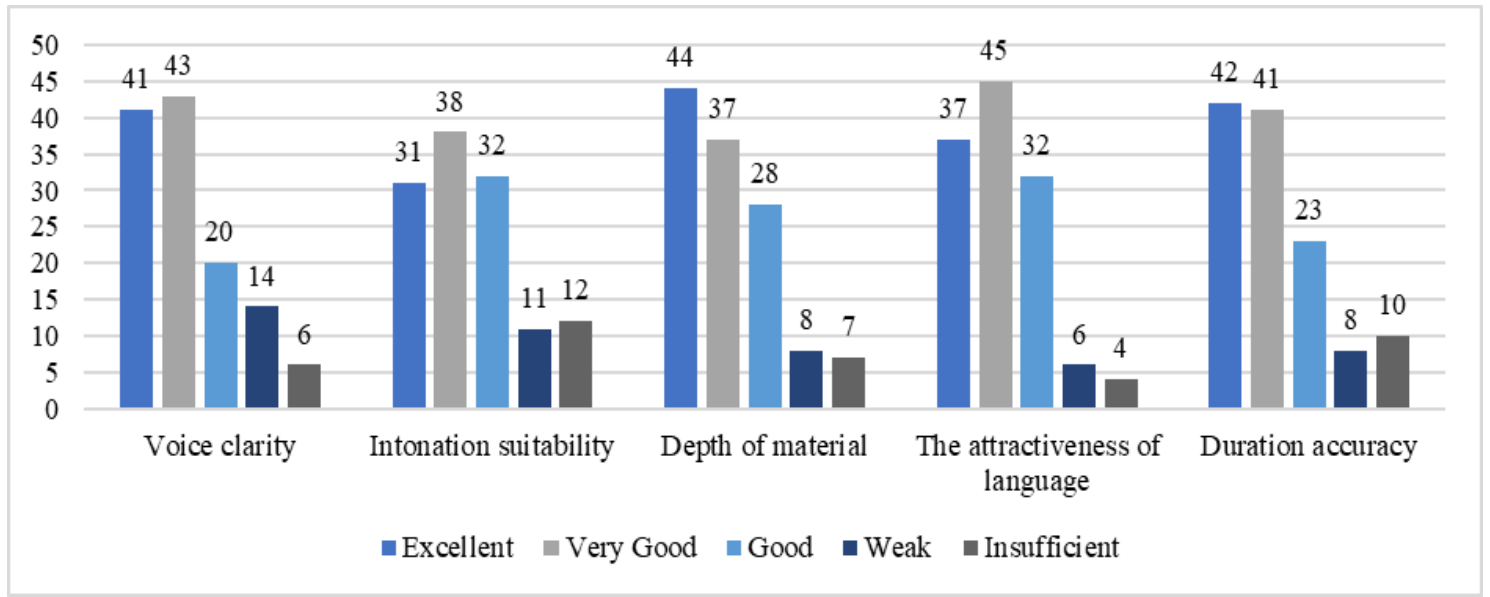

Source: Research Data, 2020

Fig. 3. Respondent feedback at the operational field-testing stage 


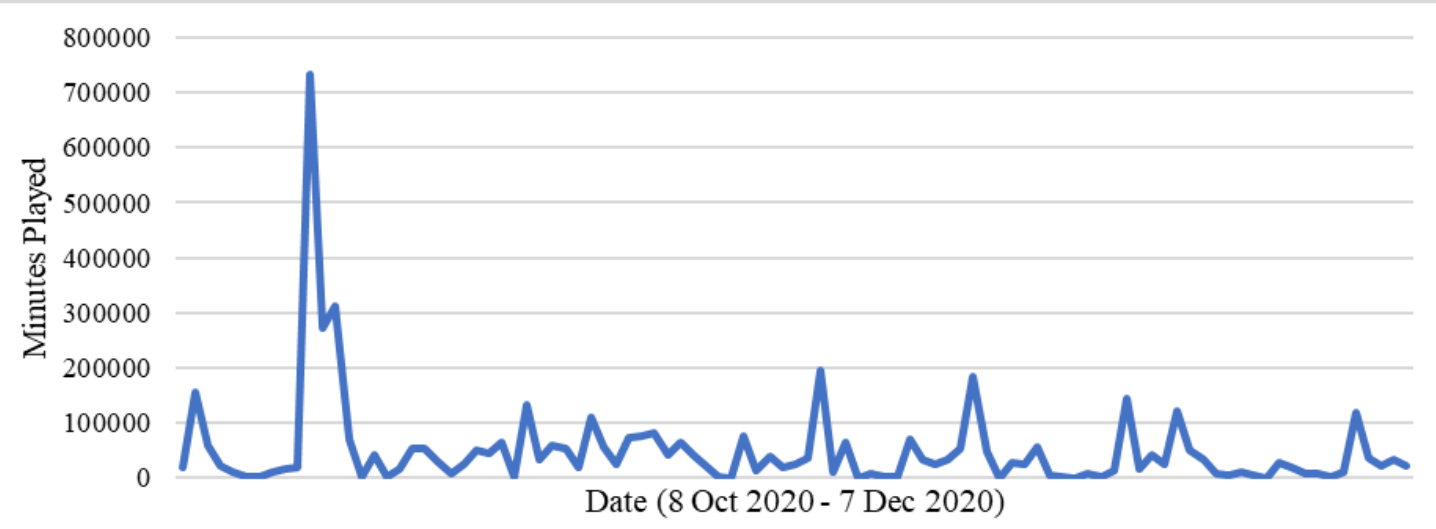

Fig. 4. Analytics data from Google Podcasts for 'Skripsi Beres!' Channel. The data show minutes played by any user in the internet from October $8^{\text {th }}$, 2020 to December $7^{\text {th }}, 2020$. Average minutes played are 50.085 minutes.

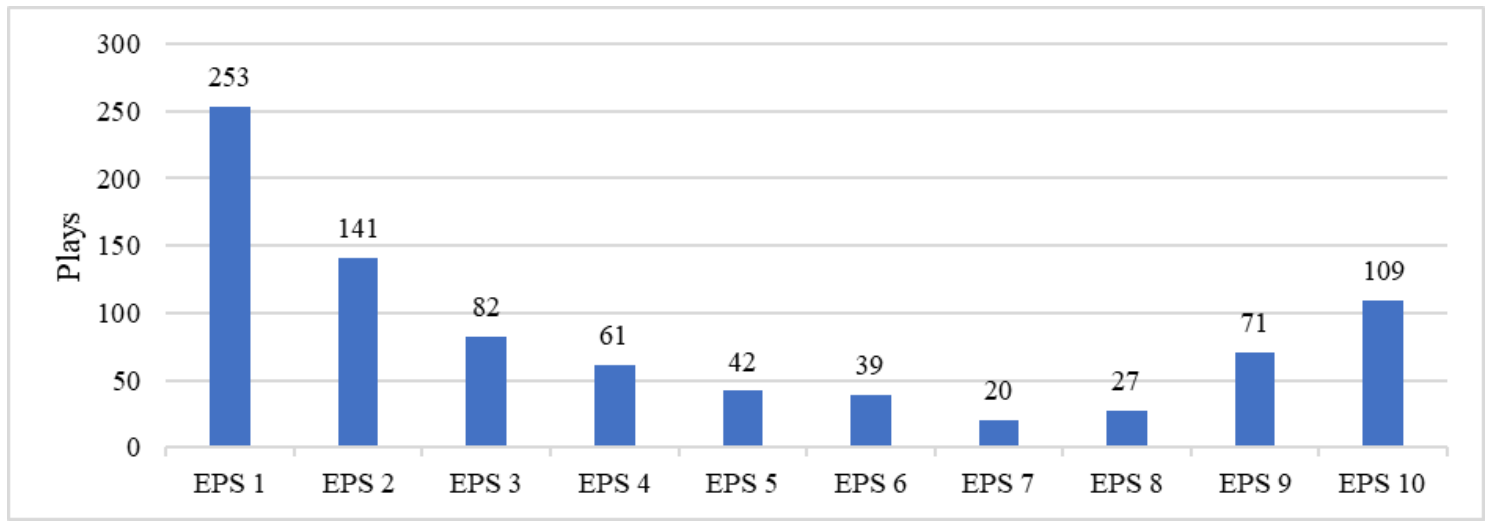

Source: Google Analytics, 2020

Fig. 5. Analytics data from Google Podcasts for 'Skripsi Beres!' Channel. The data show meaningful plays by any user in the internet from October $8^{\text {th }}$, 2020 to December $7^{\text {th }}, 2020$. A meaningful play is when a user listens for at least 5 seconds to an episode.

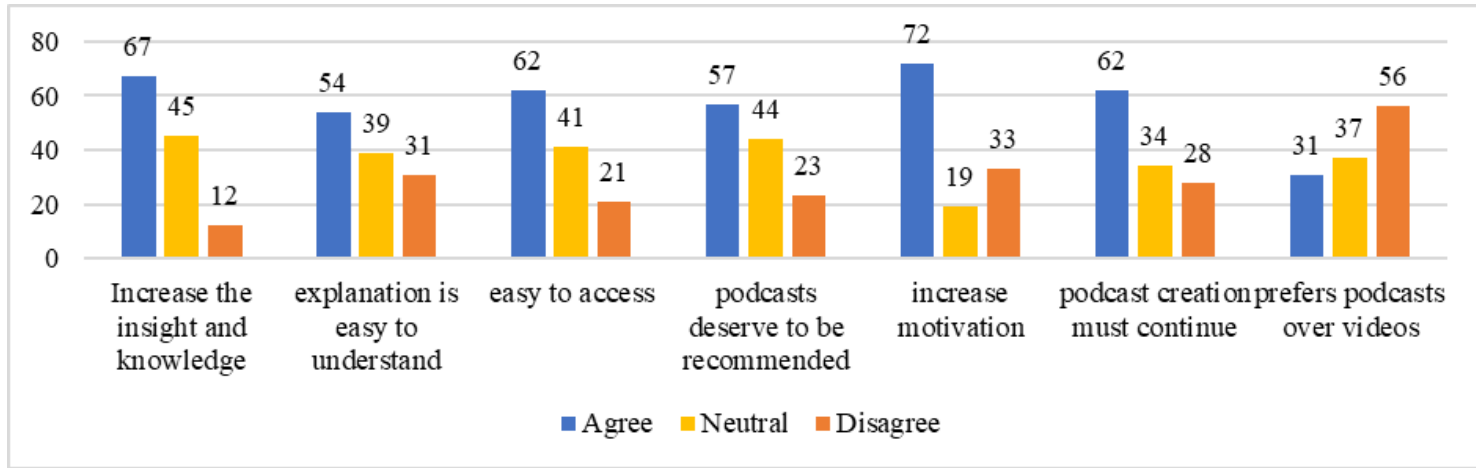

Source: Research Data, 2020

Fig. 6. Respondents' feedback for the final version of podcasts in channel 'Skripsi Beres!'.

\section{Effectiveness of Using Podcasts as Online Teaching Materials}

The results showed that podcasts development needs to pay attention to several aspects, such as voice clarity, intonation suitability, depth of material, the attractiveness of language, and duration accuracy. Voice clarity and intonation suitability affect the comfort of students in listening to content so that their chances of capturing messages from podcasts are higher. Depth of material affects the benefits they receive after listening to podcasts. However, the depth of material that is too high can make students unable to digest information so that its 
suitability needs to be considered. Meanwhile, the attractiveness of language and duration accuracy affects student retention so that students can listen to all parts of the podcasts without missing anything from learning.

Podcasts developed on the channel 'Skripsi Beres!' is a podcast that is developed based on these five things. These steps were taken so that students could learn through online media that was accessible and effective in increasing their understanding. Data on Google Analytics and feedback from students show that these podcasts are quite effective in supporting online learning. Students thought that delivering lectures via podcasts could increase their knowledge in a pleasure way. In addition, students also agree that the use of podcasts can reduce their consumption of internet costs. Even so, the majority of students disagreed that podcasts were better than online videos like YouTube. Although the cost of the internet to access online videos is higher, its effectiveness in supporting online learning is still superior to podcasts.

\section{CONCLUSION}

The output of this research is the podcast 'Skripsi Beres!' which can be accessed on the Google Podcasts website. Channel 'Skripsi Beres!' has 10 episodes which can be accessed by students via smartphone or laptop. The measure of the success of this actualization activity is student feedback on the podcast 'Skripsi Beres!'. Based on the results of feedback from students, it can be concluded that this podcast can be an alternative teaching material in online learning in higher education.

\section{RECOMMENDATION}

The use of podcasts has become a common phenomenon among higher education students. But until now, there has been very little reference and research on the impact of podcasts on learning outcomes. Therefore, this article recommends that further researchers conduct research on the relationship between podcasts and learning outcomes and 21st century thinking skills.

\section{REFERENCES}

[1] A. Popova and P. Edirisingha, "How can podcasts support engaging students in learning activities?," Procedia - Soc. Behav. Sci., vol. 2, no. 2, pp. 5034-5038, 2010.

[2] J.L. Hargett, "Podcasting in Nursing Education: Using Commercially Prepared Podcasts to Spark Learning," Teach. Learn. Nurs., vol. 13, no. 1 , pp. 55-57, 2018.

[3] A. Fachriza, "The Effect of Audio Podcast Application on Guessing Meaning Skill on Teaching Listening Comprehension," Educ. J. Pendidik. Islam, vol. 4, no. 1, 2020.

[4] F. Indriastuti and W.T. Saksono, "Podcast sebagai Sumber Belajar Berbasis Audio," J. Teknodik, vol. 18, no. 3, 2014

[5] A.C. Nwosu, D. Monnery, V.L. Reid, and L. Chapman, "Use of Podcast Technology to Facilitate Education, Communication and Dissemination in Palliative Care: The Development of The Amipal Podcast," BMJ Support. Palliat. Care, vol. 7, no. 2, pp. 212-217, Jun. 2017.

[6] K.F. Hew, "Use of Audio Podcast in K-12 and Higher Education: A Review of Research Topics and Methodologies," Educ. Technol. Res. Dev., vol. 57, no. 3, pp. 333-357, Jun. 2009.

[7] S. McClung and K. Johnson, "Examining the Motives of Podcast Users," J. Radio Audio Media, vol. 17, no. 1, pp. 82-95, May 2010.

[8] B.C. Jham, G.V. Duraes, H.E. Strassler, and L.G. Sensi, "Joining the Podcast Revolution,” J. Dent. Educ., vol. 72, no. 3, pp. 278-281, Mar. 2008 .

[9] Hilmatunisa, D. Miranty, and R. Rima, "The Influence of Using Podcast in Teaching Selective Listening of SMAN 2 Kota Serang," Bebasan J. Ilm. Kebahasaan dan Kesastraan, vol. 5, no. 2, pp. 97-108, 2018.

[10] S. Şendağ, N. Gedik, and S. Toker, "Impact of Repetitive Listening, Listening-Aid and Podcast Length on EFL Podcast Listening," Comput. Educ., vol. 125, pp. 273-283, Oct. 2018.

[11] C. Evans, "The Effectiveness of m-Learning in The Form of Podcast Revision Lectures in Higher Education," Comput. Educ., vol. 50, no. 2, pp. 491-498, Feb. 2008.

[12] H. Harris and S. Park, "Educational Usages of Podcasting," Br. J. Educ. Technol., vol. 39, no. 3, pp. 548-551, May 2008.

[13] R. Berry, "Will the iPod Kill the Radio Star? Profiling Podcasting as Radio," Converg. Int. J. Res. into New Media Technol., vol. 12, no. 2, pp. 143-162, May 2006. 